\title{
Acute citrulline oral supplementation induces greater post-exercise hypotension response in hypertensive than normotensive individuals
}

\author{
Suplementação oral aguda de citrulina induz \\ maior resposta hipotensiva pós-exercício \\ em indivíduos hipertensos \\ do que normotensos
}

\author{
Kamila GRANDOLFI ${ }^{1}$ iD 0000-0002-8286-6072 \\ João Vagner CAVALARI ${ }^{1}$ (D) 0000-0003-3980-0040 \\ Renata Cristina GÓES ${ }^{1}$ (D) 0000-0002-3100-3197 \\ Marcos Doederlein POLITO2 (iD) 0000-0002-6720-007X \\ Juliano CASONATTO1 (iD) 0000-0001-5397-5694
}

\section{A B S T R A C T}

\section{Objective}

To investigate whether acute citrulline supplementation might influence post-exercise hypotension in normotensive and hypertensive individuals.

\section{Methods}

Following a randomized double-blind design, twenty normotensive $(28 \pm 7$ years, $74 \pm 17 \mathrm{~kg}, 1.7 \pm 0.09 \mathrm{~m})$ and 20 hypertensive individuals $(55 \pm 12$ years, $76 \pm 15 \mathrm{~kg}, 1.59 \pm 0.09 \mathrm{~m})$ were randomly assigned to one of the four

${ }^{1}$ Universidade Norte do Paraná, Centro de Ciências da Saúde, Departamento de Educação Física. R. Marselha, 591, Jd. Piza, 86041-140, Londrina, PR, Brasil. Correspondência para/Correspondence to: J CASONATTO. E-mail: <juliano2608@hotmail.com>.

2 Universidade Estadual de Londrina, Centro de Educação Física e Esportes, Departamento de Educação Física. Londrina, PR, Brasil.

Based on the dissertation by K GRANDOLFI, entitled: "Impacto da suplementação de citrulina sobre o comportamento da pressão arterial pós-exercício entre normotensos e hipertensos”. Universidade Norte do Paraná; 2017.

Como citar este artigo/How to cite this article

Grandolfi K, Cavalari JV, Goes RC, Polito MD, Casonato J. Acute citrulline oral supplementation induces a greater postexercise hypotension response in hypertensive than normotensive individuals. Rev Nutr. 2018;31(6):509-21. http://

dx.doi.org/10.1590/1678-98652018000600001 
experimental groups (Normotensive-Placebo; Normotensive-Citrulline; Hypertensive-Placebo; HypertensiveCitrulline). The placebo groups ingested $6 \mathrm{~g}$ of corn starch and the citrulline groups ingested $6 \mathrm{~g}$ of citrulline dissolved in water. The participants performed 40 minutes of walking/running on a treadmill at $60-70 \%$ heart rate reserve. Blood pressure was measured immediately after a 60-min exercise session using an oscillometric device and 24-h ambulatory monitoring.

\section{Results}

The post-exercise hypotension was more pronounced in hypertensives and the Hypertensive-Citrulline group showed a consistent systolic blood pressure reduction during the laboratorial phase, which can be seen by looking at the mean of 60 minutes $(-15.01 \mathrm{mmHg}$ vs $-3.14 \mathrm{mmHg}[P=0.005] ;-4.16 \mathrm{mmHg}[P=0.009] ;-6.30 \mathrm{mmHg}$ $[P=0.033]$ in comparison with the Normotensive-Placebo, Normotensive-Citrulline, and Hypertensive-Placebo groups, respectively). During ambulatory blood pressure monitoring, the Hypertensive-Citrulline group showed a significant reduction in systolic blood pressure $(-21.05 \mathrm{mmHg})$ in the awake period compared with the Normotensive-Citrulline group $(-3.17 \mathrm{mmHg}[P=0.010])$.

\section{Conclusion}

Acute citrulline oral supplementation can induce greater post-exercise hypotension response in hypertensive than normotensive individuals.

Keywords: Blood pressure. Citrulline. Dietary supplements. Exercise. Hypertension.

\section{RE S U M O}

\section{Objetivo}

Investigar se a suplementação aguda de citrulina pode influenciar a hipotensão pós-exercício em indivíduos normotensos e hipertensos.

\section{Métodos}

Seguindo delineamento duplo-cego randomizado, vinte indivíduos normotensos (28 \pm anos, $74 \pm 17 \mathrm{~kg}$, $1,7 \pm 0,09 \mathrm{~m})$ e 20 hipertensos (55 12 anos, $76 \pm 15 \mathrm{~kg}, 1,59 \pm 0,09 \mathrm{~m}$ ) foram randomizados e distribuídos em um dos quatro grupos experimentais (Normotenso-Placebo; Normotenso-Citrulina; Hipertenso-Placebo; Hipertenso- Citrulina). Os grupos placebo ingeriram $6 \mathrm{~g}$ de amido de milho e os grupos citrulina $6 \mathrm{~g}$ de citrulina, dissolvidos em água. Os participantes realizaram 40 minutos de caminhada/corrida em esteira a uma intensidade entre $60-70 \%$ da frequência cardíaca de reserva. A pressão arterial foi aferida imediatamente após a sessão de exercício por 60 minutos usando um equipamento oscilométrico, e durante 24 horas por monitorização ambulatorial.

\section{Resultados}

A hipotensão pós-exercício foi mais pronunciada nos hipertensos e o grupo Hipertenso-Citrulina mostrou uma redução consistente da pressão arterial sistólica durante a fase laboratorial, o que pode ser visto pela média de 60 minutos $(-5,01 \mathrm{mmHg}$ vs $-3,14 \mathrm{mmHg}[P=0,005] ;-4,16 \mathrm{mmHg}[P=0,009] ;-6,30 \mathrm{mmHg}[P=0,033]$ em comparação com o Normotenso-Placebo, Normotenso-Citrulina e Hipertenso-Placebo, respectivamente). Durante a monitorização ambulatorial da pressão arterial, o Hipertenso-Citrulina demonstrou uma redução significativa na pressão arterial sistólica $(-21,05 \mathrm{mmHg})$ durante a vigília em comparação com o NormotensoCitrulina $(-3,17 \mathrm{mmHg}[P=0,010])$.

\section{Conclusão}

A suplementação oral aguda de citrulina induz maior resposta hipotensiva pós-exercício em indivíduos hipertensos do que normotensos.

Palavras-chave: Pressão arterial. Citrulina. Suplementos alimentares. Exercício. Hipertensão.

\section{N T RO D U C T I O N}

Post-Exercise Hypotension (PEH) is defined as a sustained reduction in Blood Pressure (BP) after a single bout of exercise
[1] and this transient reduction can last up to $24 \mathrm{~h}$ after completion of an exercise session [2]. PEH is an important physiological event in both hypertensive [3] and pre-hypertensive individuals [4] due to its association with the 
chronic reduction in resting BP provided by physical training. In this sense, subjects who exhibit a greater drop in BP after an exercise session (acute effect) can present a greater reduction in resting $\mathrm{BP}$ after training (chronic effect). Thus, PEH suggests the possibility of predicting responders and non-responders to $\mathrm{BP}$ adjustments after exercise training [5].

PEH is related to several peripheral hemodynamic changes, including reductions in total peripheral resistance and cardiac output [6]. Nevertheless, reports appear to vary from normotensive to hypertensive individuals. Previous studies reported that hypertensive individuals present cardiac output reduction $[7,8]$ and normotensives present total peripheral resistance reduction $[7,9,10]$. A large body of evidence has demonstrated a critical role of Nitric Oxide (NO) in blood pressure regulation. Released from endothelial cells, NO increases 3'5'-Cyclic-Guanosine Monophosphate (cGMP) production and subsequent cGMP-dependent protein kinase activation in vascular smooth muscle cells, resulting in vasodilation $[11,12]$.

Related to this point, several studies have persuasively demonstrated that citrulline (a nonessential amino acid) has a key role in the arginine-nitric oxide system, increasing NO bioavailability [13], and that chronic citrulline supplementation decreased total peripheral resistance, implying in a reduction in mean arterial pressure and diastolic pressure [14]. Thus, it is possible that PEH could be more pronounced after citrulline supplementation.

Additionally, blood pressure responses may be different as PEH can be caused by different mechanisms between normotensive and hypertensive individuals. Therefore, we could expect that single dose of citrulline oral supplementation may acutely contribute to improving the peripheral vasodilation mechanisms in hypertensive individuals, resulting in greater PEH magnitude and/or duration.

Accordingly, the aim of the present study was to investigate whether acute citrulline supplementation might influence $\mathrm{PEH}$ in normotensive and hypertensive individuals. We hypothesized that the PEH would be more pronounced in hypertensive individuals after citrulline supplementation.

\section{METHODS}

\section{Participants}

After sample size calculation (see statistical analysis section), 40 individuals (20 normotensives and 20 hypertensives) who were sedentary (less than 150 minutes per week of moderate physical activities) participated in the study. Volunteers were adult women or men without osteoarticular disabilities and medical clearance to exercise. Participants were recruited from a community-based outreach exercise program offered by the university that provided stretching and functional exercise sessions to the outside community. The study followed the Declaration of Helsinki and was approved by the Research Ethics Committee of the university (78697617.4.0000.0108). All participants were informed about the methods before giving written informed consent.

\section{Study design}

This was an acute, randomized, doubleblind, placebo-controlled study to evaluate the effects of citrulline supplementation on $\mathrm{PEH}$ in normotensive and hypertensive individuals. The participants were randomly allocated (using a random number table - https://www.random. org/) into four different experimental groups (Normotensive-Placebo [NP]; NormotensiveCitrulline $[\mathrm{NC}]$; Hypertensive-Placebo [HP]; Hypertensive-Citrulline [HC]). Supplementation was performed in a double-blind design. The participants ingested a sachet containing citrulline (6 grams) or placebo (6 grams of cornstarch) dissolved in $120 \mathrm{~mL}$ of water. 
The substances were ingested 120 minutes before the experimental session. Anthropometric measures were taken before the rest period. The experimental session consisted of a 5-min warm up ( $50 \%$ of $65 \%$ HR reserve) and 40 minutes of running/walking at $60-70 \% \mathrm{HR}$ reserve on a treadmill. This was followed by a progressive speed reduction until the subject was walking, which lasted 5 minutes (cooldown).

After the exercise sessions, the blood pressure was measured every 10 minutes over a course of 60 minutes. The participants were then allowed 15 minutes to take a shower and change their clothes before the ambulatory blood pressure device was attached to their arm. The ambulatory blood pressure was recorded for 24 hours. The participants were asked to return to the laboratory the following day to remove the device.

The schematic representation of the experimental design is shown in Figure 1. Data collection occurred between January and July 2018. The study protocol was registered in ClinicalTrials.gov (NCT03378596).

\section{Anthropometry}

Weight was measured using a digital anthropometric scale (Urano, OS180A, Canoas,
Brazil), with an accuracy of $0.1 \mathrm{~kg}$ and height was measured using a stadiometer with an accuracy of $0.1 \mathrm{~cm}$, according to the procedures described by Gordon et al. [15]. The Body Mass Index (BMI) was established by dividing body weight $(\mathrm{kg})$ by squared height. The waist circumference (midpoint between the iliac crest and last rib) was determined using an inextensible tape (Sanny ${ }^{\circledR}$, São Paulo, Brazil) with an accuracy of $0.001 \mathrm{~m}$.

\section{Office Blood Pressure (laboratorial phase)}

Office blood pressure was measured using an oscillometric monitor (Omron MX3 Plus, Bannockburn, United States) previously validated for clinical measures in adults [16]. First the participants remained seated (rest period) in a calm, quiet, and thermoneutral $\left(22^{\circ}-24^{\circ} \mathrm{C}\right)$ environment for $20 \mathrm{~min}$. The blood pressure was measured three times during the rest period (at $10 \mathrm{~min}, 15 \mathrm{~min}$, and 20min). The mean value of the three blood pressure measurements was used as the resting blood pressure value. Immediately following the sessions (exercise or control), the blood pressure was measured

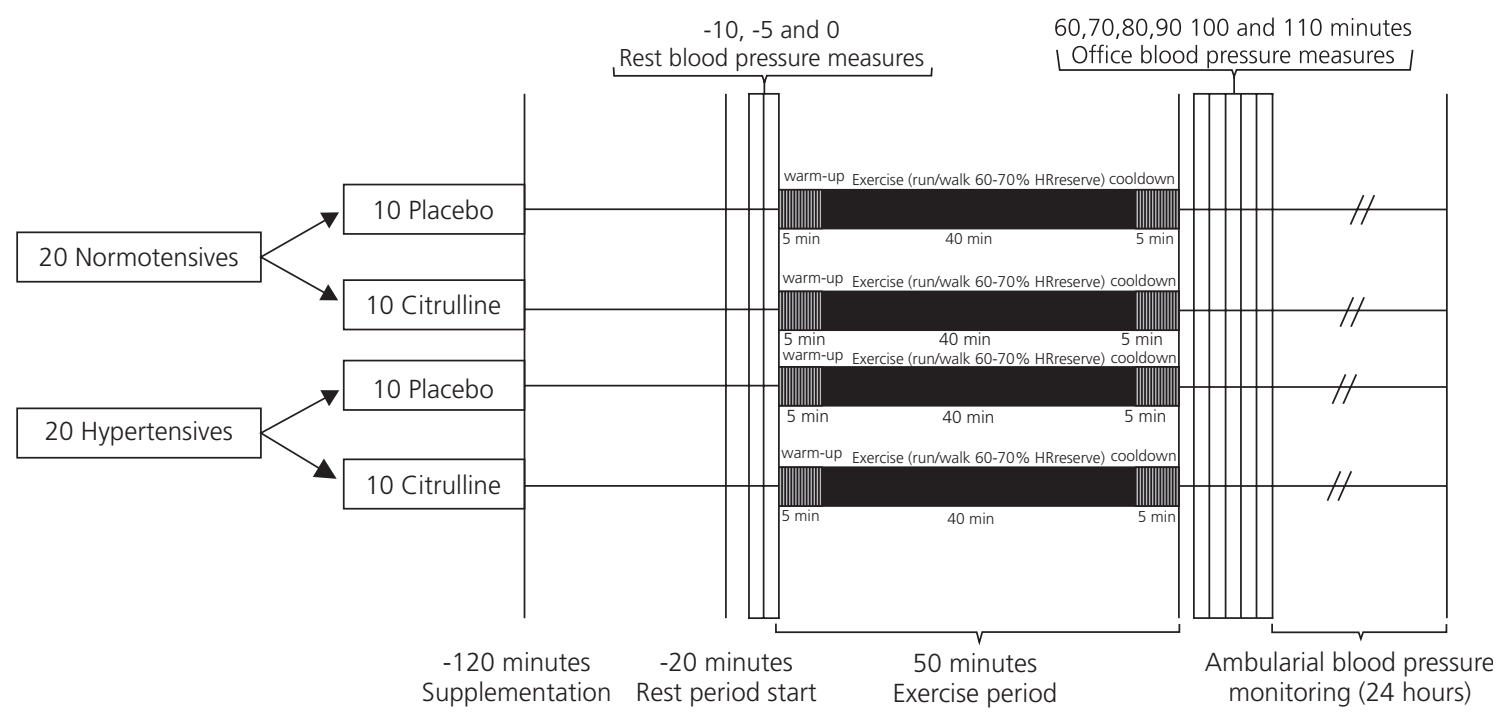

Figure 1. Schematic representation of experimental design. Londrina (PR), Brazil, 2018 
in a quiet environment for 60 minutes. The blood pressure measurements were taken in accordance with the American Heart Association recommendations [17].

\section{Ambulatory blood pressure monitoring (ambulatory phase)}

The ambulatory blood pressure was measured using an oscillometric device (DynaMAPA, São Paulo, Brazil) attached to the left arm, always by the same investigator, in accordance with the procedures described by the American Heart Association [17]. The participants received instructions to hold their arm outstretched during the measurements. The device was calibrated by direct comparison with a mercury sphygmomanometer by a trained technical person, in agreement with recommendations [17].

The monitor was set to record the systolic and diastolic blood pressure and heart rate every 20 minutes, except during the nighttime (23h00min to 08 h00min) when the readings were taken every 30 minutes to minimize sleep disturbance. The device screen was blinded to the subject to avoid feedback. All participants were instructed to record and report their sleep time in a diary the following day.

The data were stored in the device memory and then transferred to a computer using a specific software (Aplicação Dyna Mapa, version 5.0.382.12, São Paulo, Brazil) for analysis. The average of valid readings was above 90\% for all participants. The delta between the rest period and mean arterial blood pressure monitoring (awake, asleep, and 24 hours) was calculated for analysis.

\section{Statistical analysis}

A total of 7 subjects per group would be needed to detect a minimum difference of $7 \mathrm{mmHg}$ [18] with $80 \%$ power and an alpha of $5 \%$, assuming a Standard Deviation (SD) of $5 \mathrm{mmHg}$ for the systolic blood pressure.

The data are reported as mean and standard error. One-way Analysis of Variance (ANOVA) was used to compare the characteristics of participants.

To compare the absolute values between experimental groups, Mauchly's test of sphericity was applied first followed by the GreenhouseGeisser correction if necessary. Next, these data were compared with a one-factor repeated measures General Linear Model (GLM). Fisher's multiple comparison test was used to examine differences between pairs of trials.

To compare the delta values for each period between the groups, Levene's test for equality of variances was applied and corrected if necessary. Next, the data were compared with an independent samples $t$-test.

Effect size from the paired $t$-test was calculated $(d=$ mean/SD). Statistical significance was defined as $P<0.05$. The statistical analysis was generated using Statistical Package for the Social Sciences (SPSS Inc., Chicago, Illinois, United States) version 20, for Windows.

\section{RES U L T S}

Descriptive statistics for age, weight, height, body mass index, waist circumference, and resting systolic and diastolic blood pressure values for participants in each group and an overview of the antihypertensive drug profile of each of the hypertensive experimental groups are shown in Table 1. The hypertensive individuals presented higher values for age, body mass index, waist circumference, and resting systolic and diastolic blood pressure when compared with both normotensive groups.

\section{Intragroup post-exercise hypotension (absolute values)}

The HC presented systematic reductions (absolute value comparison - Table 2[A]) in 
Table 1. General characteristics of participants. Londrina (PR), Brazil, 2018.

\begin{tabular}{|c|c|c|c|c|c|c|c|c|c|}
\hline \multirow[t]{2}{*}{ Genereal characteristics } & \multicolumn{2}{|c|}{$\begin{array}{c}\mathrm{NP}(\mathrm{n}=10) \\
{[\mathrm{M} 4-\mathrm{F} 6]}\end{array}$} & \multicolumn{2}{|c|}{$\begin{array}{c}\mathrm{NC}(\mathrm{n}=10) \\
{[\mathrm{M} 6-\mathrm{F} 4]}\end{array}$} & \multicolumn{2}{|c|}{$\begin{array}{c}\mathrm{HP}(\mathrm{n}=10) \\
{[\mathrm{M} 4-\mathrm{F} 6]}\end{array}$} & \multicolumn{2}{|c|}{$\begin{array}{c}\mathrm{HC}(\mathrm{n}=10) \\
{[\mathrm{M} 2-\mathrm{F} 8]}\end{array}$} & \multirow[b]{2}{*}{$P$} \\
\hline & Mean & SE & Mean & SE & Mean & SE & Mean & SE & \\
\hline Age (years) & 27.70 & 2.4 & 29.90 & 2.5 & 52.00 & $4.8^{* \dagger}$ & 58.60 & $2.7^{* \dagger}$ & $<0.001$ \\
\hline Weight (kg) & 70.90 & 6.2 & 76.40 & 4.6 & 79.60 & 5.5 & 72.50 & 4.1 & 0.629 \\
\hline Height (m) & 1.69 & 0.03 & 1.71 & 0.03 & 1.61 & $0.03^{+}$ & 1.58 & $0.03^{* \dagger}$ & 0.008 \\
\hline $\mathrm{BMI}\left(\mathrm{kg} / \mathrm{m}^{2}\right)$ & 24.40 & 1.5 & 25.90 & 1.1 & 30.80 & $2.1^{*+}$ & 29.20 & $1.8^{* \dagger}$ & 0.038 \\
\hline WC $(\mathrm{cm})$ & 79.30 & 4.3 & 84.40 & 3.5 & 98.50 & $4.7^{*+}$ & 99.10 & $3.5^{* \dagger}$ & 0.002 \\
\hline $\mathrm{SBP}(\mathrm{mmHg})$ & 116.00 & 5.0 & 120.00 & 4.0 & 137.00 & $4.0^{*+}$ & 142.00 & $6.0^{* t}$ & 0.001 \\
\hline $\mathrm{DBP}(\mathrm{mmHg})$ & 71.00 & 3.0 & 74.00 & 2.0 & 86.00 & $3.0^{*+}$ & 86.00 & $3.0^{* t}$ & 0.002 \\
\hline Antihypertensive drugs & & & & & $\mathrm{n}$ & & $n$ & & \\
\hline Beta-blocker & & & & & 5 & & 3 & & \\
\hline Angiotensin-converting-enzyme inhibitor & & & & & 4 & & 6 & & \\
\hline $\begin{array}{l}\text { Diuretic } \\
\text { All drugs }\end{array}$ & & & & & 1 & & $\begin{array}{l}1 \\
-\end{array}$ & & \\
\hline
\end{tabular}

Note: ${ }^{*} P<0.05$ vs NP; ${ }^{\dagger}: P<0.05$ vs NC.

NP: Normotensive-Placebo group; NC: Normotensive-Citrulline group; HP: Hypertensive-Placebo group; HC: Hypertensive-Citrulline group; M: Male; F: Female; SE: Standard Error; BMI: Body Mass Index; WC: Waist Circumference; SBP: resting Systolic Blood Pressure; DBP: resting Diastolic Blood Pressure.

relation to pre-exercise values $(-11 \%[P=0.006]$; $-12 \%[P=0.001] ;-1 \%[P=0.003] ;-9 \%[P=0.007] ;$ $-11 \%[P=0.001]$ and $-10 \%[P=0.001]$ at 10 , $20,30,40,50$, and 60 minutes post-exercise, respectively). Therefore, the HC presented systolic blood pressure reductions in mean office $(-11 \%[P<0.001]) \quad$ [laboratorial phase] and 24-hour blood pressure $(-12 \%[P=0.020])$ [ambulatory phase].

The NC also presented systolic blood pressure reductions $(-6 \%[P=0.024] ;-6 \%[P=0.049]$; $-6 \%[P=0.004]$, at 40,50 , and 60 minutes post-exercise, respectively). Likewise, the NC presented systolic blood pressure reductions in mean office $(-3 \%[P=0.031])$ [laboratorial phase] and 24-hour blood pressure $(-6 \%[P=0.048])$ [ambulatory phase]. There were no statistically significant differences in the NP and HP.

Considering diastolic blood pressure, the $\mathrm{HC}$ demonstrated reductions $(-17 \%[P<0.001])$ in the mean 24 hours.

Table 2[B] presents the effect sizes from the paired $t$ test (mean rest vs mean 60 min, mean awake, mean asleep, and mean 24 hours) for each experimental group. Considering systolic BP, the NP showed a significant effect for the asleep period, the NC showed a significant effect for the $60 \mathrm{~min}$ and asleep period, and the $\mathrm{HC}$ showed a significant effect for all periods (60 min, awake, asleep, and 24 hours). Additionally, considering diastolic BP, the NP and NC presented a significant effect for the asleep period, the HP and HC presented a significant effect for the awake, asleep and 24-hour periods. The HP presented greater effect sizes (above 2) for the awake, asleep and 24-hour periods.

\section{Citrulline effects in normotensives and hypertensives}

Figure 2 shows the citrulline effects on PEH for normotensive and hypertensive participants through the differences (delta) in relation to rest. No significant differences were observed for normotensive participants 
Table 2. Absolute value comparisons in relation to the pre-exercise moment $(A)$ and Effect size from Paired $t$-test (versus rest $[d=m e a n / S D]$ ) (B). Londrina (PR), Brazil, 2018

\begin{tabular}{|c|c|c|c|c|c|c|c|c|}
\hline \multicolumn{9}{|l|}{ A } \\
\hline \multirow{2}{*}{$\begin{array}{l}\text { Blood pressure } \\
\text { monitoring }\end{array}$} & \multicolumn{2}{|c|}{$\mathrm{NP}$} & \multicolumn{2}{|c|}{ NC } & \multicolumn{2}{|c|}{$\mathrm{HP}$} & \multicolumn{2}{|c|}{$\mathrm{HC}$} \\
\hline & mean & SE & mean & SE & mean & SE & mean & SE \\
\hline \multicolumn{9}{|l|}{ Systolic BP } \\
\hline Pre & 116 & 5 & 120 & 4 & 137 & 4 & 142 & 6 \\
\hline $10 \mathrm{~min}$ & 117 & 4 & 123 & 3 & 129 & 3 & 127 & $3^{*}$ \\
\hline $20 \mathrm{~min}$ & 114 & 4 & 116 & 4 & 129 & 3 & 125 & $4^{*}$ \\
\hline $30 \mathrm{~min}$ & 113 & 4 & 115 & 3 & 130 & 3 & 127 & $6^{*}$ \\
\hline $40 \mathrm{~min}$ & 112 & 4 & 113 & $4^{*}$ & 133 & 6 & 129 & $6^{*}$ \\
\hline $50 \mathrm{~min}$ & 114 & 5 & 113 & $3^{*}$ & 131 & 4 & 126 & $6^{*}$ \\
\hline $60 \mathrm{~min}$ & 111 & 5 & 113 & $4^{*}$ & 130 & 4 & 128 & $6^{*}$ \\
\hline Mean 60 min & 113 & 4 & 116 & $3^{*}$ & 131 & 3 & 127 & $5^{*}$ \\
\hline Mean $24 \mathrm{~h}$ & 110 & 2 & 113 & $3^{*}$ & 127 & 3 & 125 & $4^{*}$ \\
\hline ANOVA $(P)$ & \multicolumn{2}{|c|}{0.303} & \multicolumn{2}{|r|}{0.028} & \multicolumn{2}{|c|}{0.490} & \multicolumn{2}{|r|}{0.019} \\
\hline \multicolumn{9}{|l|}{ Diastolic BP } \\
\hline Pre & 72 & 3 & 74 & 3 & 86 & 3 & 86 & 3 \\
\hline $10 \mathrm{~min}$ & 75 & 3 & 83 & 4 & 84 & 3 & 86 & 3 \\
\hline $20 \mathrm{~min}$ & 76 & 2 & 76 & 3 & 86 & 3 & 83 & 4 \\
\hline $30 \mathrm{~min}$ & 72 & 3 & 75 & 3 & 86 & 3 & 88 & 4 \\
\hline $40 \mathrm{~min}$ & 72 & 2 & 75 & 2 & 93 & 7 & 89 & 5 \\
\hline $50 \mathrm{~min}$ & 73 & 3 & 75 & 3 & 86 & 5 & 84 & 3 \\
\hline $60 \mathrm{~min}$ & 69 & 3 & 77 & 2 & 85 & 3 & 86 & 3 \\
\hline Mean 60 min & 73 & 2 & 77 & 3 & 87 & 3 & 86 & 3 \\
\hline Mean 24h & 65 & 2 & 69 & 3 & 78 & 2 & 71 & $3^{*}$ \\
\hline ANOVA $(P)$ & \multicolumn{2}{|c|}{0.047} & \multicolumn{2}{|c|}{0.050} & \multicolumn{2}{|c|}{0.101} & \multicolumn{2}{|c|}{0.007} \\
\hline \multicolumn{9}{|l|}{ B } \\
\hline \multirow{2}{*}{$\begin{array}{l}\text { Blood pressure } \\
\text { monitoring }\end{array}$} & \multicolumn{2}{|c|}{$\mathrm{NP}$} & \multicolumn{2}{|c|}{ NC } & \multicolumn{2}{|c|}{$\mathrm{HP}$} & \multicolumn{2}{|c|}{$\mathrm{HC}$} \\
\hline & ES & $P$ & ES & $P$ & ES & $P$ & ES & $P$ \\
\hline \multicolumn{9}{|l|}{ Systolic BP } \\
\hline Mean 60 min & 0.31 & 0.356 & 0.81 & 0.031 & 0.53 & 0.127 & 1.81 & $<0.001$ \\
\hline Mean awake & 0.18 & 0.578 & 0.30 & 0.361 & 0.54 & 0.120 & 1.25 & 0.003 \\
\hline Mean asleep & 1.00 & 0.011 & 1.27 & 0.003 & 0.48 & 0.161 & 1.24 & 0.004 \\
\hline Mean 24h & 0.42 & 0.220 & 0.69 & 0.057 & 0.58 & 0.102 & 0.89 & 0.020 \\
\hline \multicolumn{9}{|l|}{ Diastolic BP } \\
\hline Mean 60 min & -0.28 & 0.403 & -0.38 & 0.256 & 0.12 & 0.707 & -0.01 & 0.968 \\
\hline Mean awake & 0.51 & 0.139 & 0.06 & 0.846 & 0.81 & 0.030 & 2.06 & $<0.001$ \\
\hline Mean asleep & 0.89 & 0.020 & 1.77 & $<0.001$ & 0.90 & 0.019 & 2.16 & $<0.001$ \\
\hline Mean 24h & 0.70 & 0.054 & 0.48 & 0.161 & 0.88 & 0.021 & 2.28 & $<0.001$ \\
\hline
\end{tabular}

Note: ${ }^{*} P<0.05$ vs Pre.

NP: Normotensive-Placebo group; NC: Normotensive-Sitrulline group; HP: Hypertensive-Placebo group; HC: Hypertensive-Citrulline group; SE: Standard Error; BP: Blood Pressure; ES: Effect Size.

(panel A). Hypertensives presented a significant citrulline effect on diastolic blood pressure for the awake period $(-13.93 \mathrm{mmHg}$ vs $-6.85 \mathrm{mmHg}$ $[P=0.042]$, panel $B)$. 
Normotensives
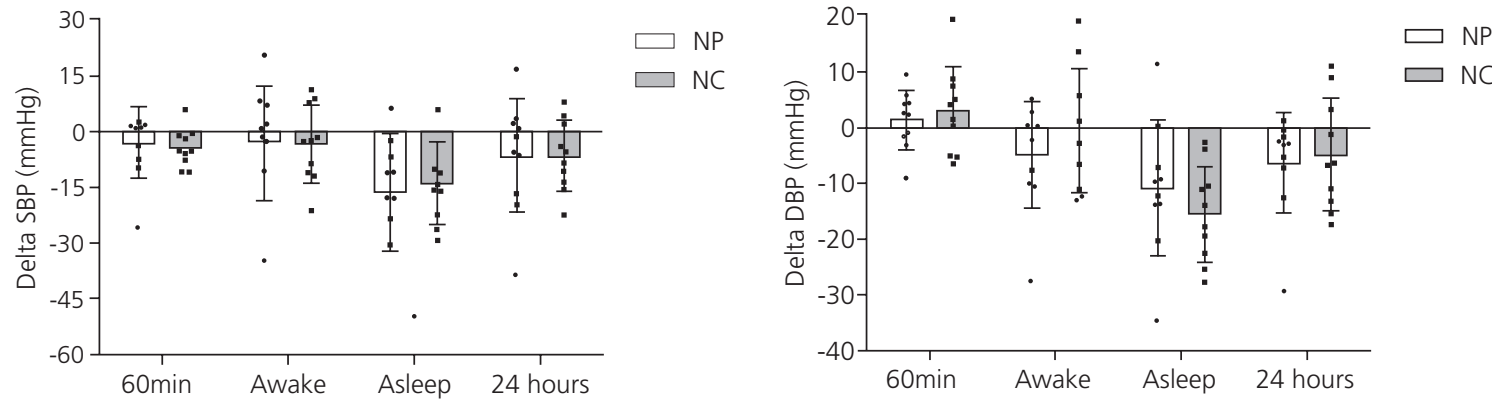

Hypertensives
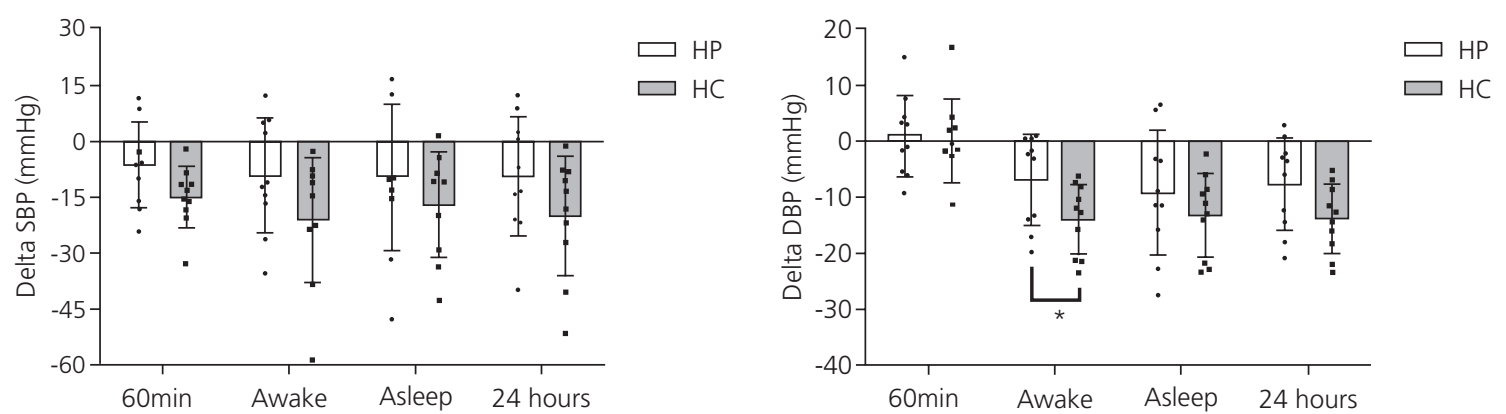

Figure 2. Citrulline effects on post-exercise hypotension for normotensives and hypertensives. Londrina (PR), Brazil, 2018.

NP: Normotensive-Placebo group; NC: Normotensive-Citrulline group; HP: Hypertensive-Placebo group; HC: Hypertensive-Citrulline group; SBP: Systolic Blood Pressure; DBP: Diastolic Blood Pressure.

\section{Placebo}
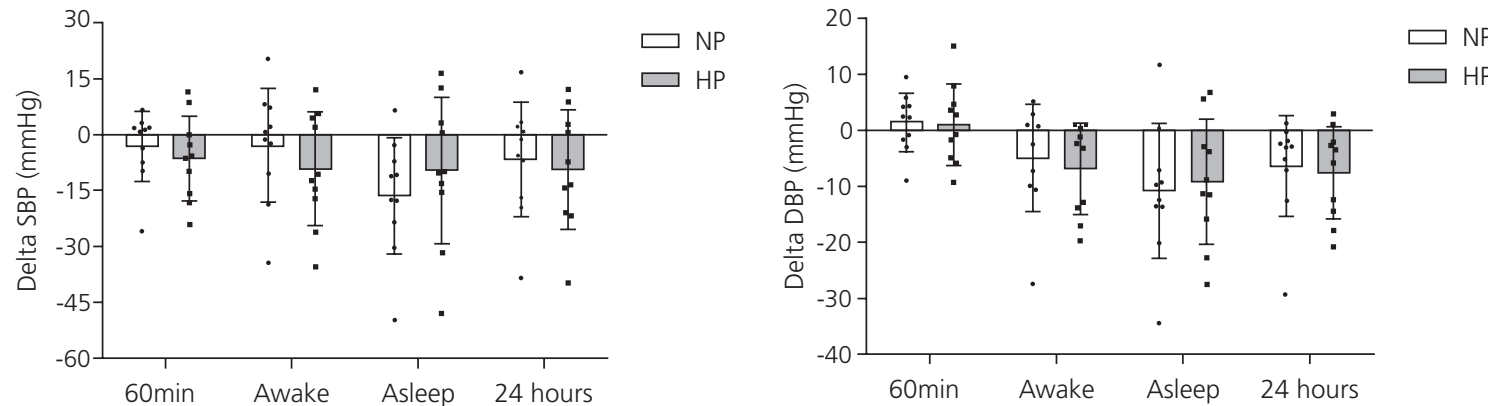

Citrulline
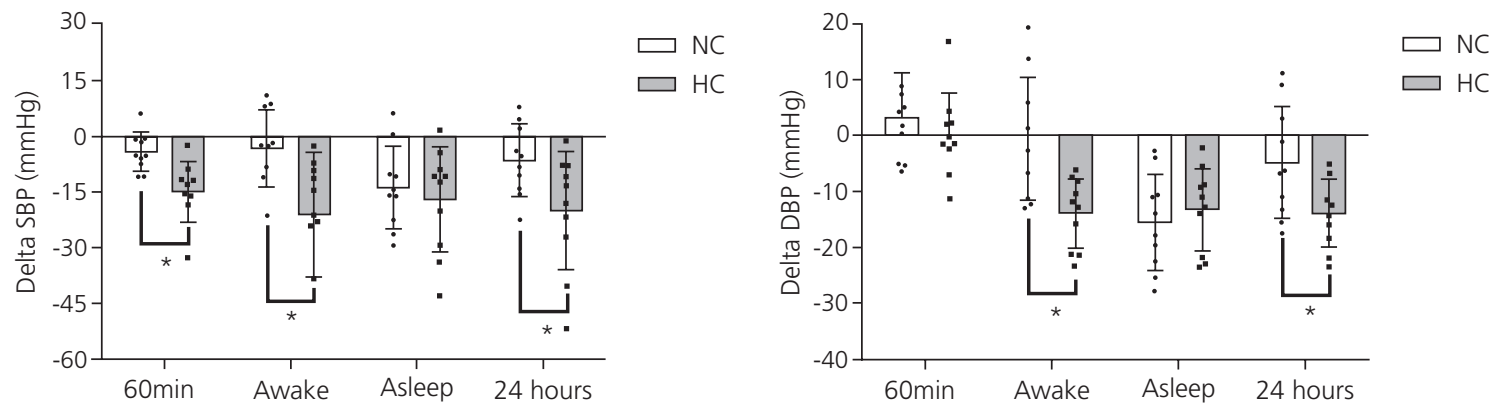

Figure 3. Citrulline effects on post-exercise hypotension between normotensives and hypertensives. Londrina (PR), Brazil, 2018. NP: Normotensive-Placebo group; NC: Normotensive-Citrulline group; HP: Hypertensive-Placebo group; HC: Hypertensive-Citrulline group; SBP Systolic Blood Pressure; DBP: Diastolic Blood Pressure. 


\section{Citrulline effects between normotensives and hypertensives}

Figure 3 shows the effects of one isolated acute citrulline supplementation on PEH between normotensives and hypertensives. No significant differences were observed between groups for placebo conditions (panel A). Considering the citrulline supplementation groups, hypertensive participants presented a higher reduction in systolic blood pressure when compared with the normotensives during the laboratorial phase $(60 \mathrm{~min})(-15.01 \mathrm{mmHg}$ vs $-3.99 \mathrm{mmHg}$ $[P=0.002]$, awake $(-21.05 \mathrm{mmHg}$ vs $-3.17 \mathrm{mmHg}$ $[P=0.01]$ and 24 -hour periods $(-20.02 \mathrm{mmHg}$ vs $-6.58 \mathrm{mmHg}[P=0.033]$. Similar responses were observed for diastolic blood pressure during the awake $(-13.93 \mathrm{mmHg}$ vs $-0.53 \mathrm{mmHg}$ $[P=0.004]$ and 24 -hour periods $(-13.83 \mathrm{mmHg}$ vs $-4.79 \mathrm{mmHg}[P=0.026]$.

\section{DISCUSSION}

The purpose of the present study was to compare the effects of oral citrulline supplementation on the $\mathrm{PEH}$ response in normotensive and hypertensive subjects. Studies involving citrulline oral supplementation are relatively recent, starting around the year 2000. To the best of our knowledge, the purpose of this study of combined non-pharmacological treatments (aerobic exercise and citrulline) for hypertensives and normotensives appears to be unpublished. Therefore, it is difficult to compare these findings with other studies.

Investigations have shown that citrulline oral supplementation is related to improvement of physical activity performance, since its effect on the body promotes changes in the muscle metabolism, facilitating energy production from the aerobic system [19].

Improvement in the aerobic metabolism seems to be related to the increasing plasma levels of arginine, citrulline, and consequently, NO concentration [20]. Previous studies reported that oral citrulline supplementation raises plasma arginine concentration and increases NO production through the citrulline-NO cycle $[21,22]$. It is exactly because of this vasodilation resulting from greater NO release that citrulline oral supplementation might potentiate the $\mathrm{PEH}$ response, especially in hypertensive individuals.

Some evidence suggests a blood pressure reduction after citrulline supplementation [23]. Decreases in systolic and diastolic blood pressure $(\sim 7 / 3 \mathrm{mmHg})$ and aortic pressure $(\sim 9 / 3 \mathrm{mmHg})$ have been observed when $6 \mathrm{~g} /$ day- 1 of citrulline was administered orally in obese, pre-hypertensive and hypertensive individuals [24].

The hypothesis was that blood pressure responses would be different among groups, as PEH can be caused by different mechanisms between normotensive and hypertensive individuals. Previous studies have shown that hypertensive individuals present a deficiency in peripheral vasodilation modulators, as a compensation mechanism, so the autonomous nervous system can work to reduce cardiac output $[7,8]$. On the other hand, normotensive individuals have shown a reduction in peripheral vascular resistance $[7,9,10]$.

Additionally, hypertensive individuals can present an increase in peripheral vascular resistance [25]. Therefore, we could expect that citrulline oral supplementation may contribute to improving the peripheral vasodilation mechanisms in hypertensive individuals, resulting in a greater magnitude and/or duration of $\mathrm{PEH}$.

The ages, waist circumference and BMI of patients (normotensives vs hypertensives) were different. These differences need to be considered. On the other hand, post-exercise hypotension can occur irrespective of age [26]. A recent meta-analytic investigation [27] showed a weak correlation between age and postexercise hypotension in both systolic $(r=0.21)$ and diastolic $(r=0.12)$ blood pressure. Weak correlations were also observed between BMI and post-exercise hypotension in both systolic $(r=0.26)$ and diastolic $(r=0.09)$ blood pressure. 
The main novel findings from this study were that a single dose of supplementation with citrulline enhanced the magnitude and duration of PEH in hypertensive individuals. These findings are important as they suggest that citrulline might be responsible for the positive effects on blood pressure and offer new insights into nonpharmacological treatment for hypertension.

Therefore, evidence has accumulated demonstrating the critical role of $\mathrm{NO}$ in blood pressure regulation. Once $\mathrm{NO}$ is released from endothelial cells, it increases $3^{\prime}, 5^{\prime}$-cyclicuanosine monophosphate (cGMP) production and subsequent cGMP-dependent Protein Kinase (PKG) activation in Vascular Smooth Muscle Cells (VSMC), resulting in vasodilation $[11,12,28]$. Previous studies have confirmed the essential role of $\mathrm{NO}$ in vasorelaxation of large human arteries [29] and evidence suggests that NO production is enhanced after citrulline supplementation [21,30,31] and citrulline can restore NO production in conditions where NO production is compromised $[32,33]$. Given that NO production is one of the central pathogenic mechanisms of hypertension, restoration of adequate NO in the blood vessels may serve as an important therapeutic strategy for hypertension.

On the other hand, all current treatment guidelines [34] emphasize the role of physical activity/ exercise in the treatment of hypertension. To date, only one randomized clinical trial combining physical activity/exercise and citrulline supplementation in the treatment of hypertension was found [35]. The authors investigated the post-exercise blood pressure response 10 minutes after resistance exercise with citrulline supplementation (8 grams) and there was a significant reduction in diastolic BP [35]. In the present study, we observed hypotensive effects following 10 minutes post-exercise. Furthermore, in the previous investigation [35], the participants were submitted to a resistance exercise session, which is an important methodological difference that needs to be addressed, since in the present study the participants were asked to perform an aerobic treadmill exercise session. It is well established that aerobic exercise is an efficient strategy to reduce blood pressure $(5-15 \mathrm{mmHg})$ compared to resistance training $(5 \mathrm{mmHg})$ [36-39]; thus, differences between exercise types do not allow a direct comparison. Another important difference between the present study and previous investigations [35] is related to the "training status". Some data suggest that chronic resistance training can decrease $\mathrm{PEH}$ magnitude $[40,41]$. On the other hand, aerobic training apparently does not reduce PEH [27].

In the present study, PEH were confirmed only in the groups that ingested citrulline. It is suggested that oral citrulline supplementation might cause an additional effect on blood pressure reduction. This association (exercise + citrulline supplementation) showed expressive effects immediately after exercise with a significant reduction in systolic blood pressure during the office blood pressure period. During the ambulatory blood pressure monitoring, the HC showed significant reductions in diastolic blood pressure (Figure 2) in the awake period, suggesting that NO might be involved in this response and could be over stimulated by exercise and supplementation with citrulline when compared with exercise alone.

However, one of the most common questions driving the evaluation of intervention programs is "how does this effect compare with the effects of other interventions?". Therefore, previous studies have encouraged the use of "effect size" in quantitative studies [42]. Researchers are often encouraged to report effect sizes for three reasons. First, to present the magnitude of the reported effects in a standardized metric; second, effect sizes allow researchers to draw meta-analytic conclusions by comparing standardized effect sizes across studies; and third, effect sizes from previous studies can be used when planning a new study, providing an indication of the average sample size needed [43]. In the present study, we found that the effect sizes (from the paired $t$ test [versus rest]) were more consistent in the $\mathrm{HC}$ for systolic and diastolic ambulatorial blood 
pressure response, however, it is important to highlight that for diastolic BP the effects were "large" (above 2) for the "awake", "asleep", and "24-hour" periods in the HC.

Considering these interesting findings, further studies should include NO availability measurements, such as nitrite and nitrate. These measurements associated with the evaluation of important mechanisms such as peripheral vascular resistance and cardiac output might help us understand the action of citrulline. Furthermore, considering these promising results, further studies could associate citrulline with other potential vasodilatory nutrients and exercise modalities, enabling the development of adjuvant protocols to treat hypertension.

\section{CONCLUSION}

Acute citrulline oral supplementation can induce a greater $\mathrm{PEH}$ response in hypertensive than normotensive individuals.

\section{CONTRIBUTORS}

K GRANDOLFI, JV CAVALARI, MD POLITO and I CASONATO were responsible for the study conception and design. K GRANDOLFI, JV CAVALARI and RC GÓES performed the data collection and intervention. K GRANDOLFI, RC GÓES and J CASONATO performed the statistical analysis and interpretation of data. All authors were responsible for drafting, editing, reviewing, and approving the final version of the manuscript.

\section{ACKNOWLEDGEMENTS}

Fundação Nacional de Desenvolvimento do Ensino Superior Particular (FUNADESP).

\section{REFERENCES}

1. Kenney MJ, Seals DR. Postexercise hypotension: Key features, mechanisms, and clinical significance. Hypertension. 1993;22(5):653-64.
2. Moraes MR, Bacurau RF, Ramalho JD, Reis FC, Casarini DE, Chagas JR, et al. Increase in kinins on post-exercise hypotension in normotensive and hypertensive volunteers. Biol Chem. 2007;388(5):533-40.

3. Hecksteden A, Grutters T, Meyer T. Association between postexercise hypotension and long-term training-induced blood pressure reduction: A pilot study. Clin J Sport Med. 2013;23(1):58-63.

4. Liu S, Goodman J, Nolan R, Lacombe S, Thomas SG. Blood pressure responses to acute and chronic exercise are related in prehypertension. Med Sci Sports Exerc. 2012;44(9):1644-52.

5. Luttrell MJ, Halliwill JR. Recovery from exercise: Vulnerable state, window of opportunity, or crystal ball? Front Physiol. 2015;6:204.

6. Lloyd-Jones D, Adams R, Carnethon M, De Simone $G$, Ferguson TB, Flegal K, et al. Heart disease and stroke statistics-2009 update: A report from the American Heart Association Statistics Committee and Stroke Statistics Subcommittee. Circulation. 2009;119(3):e21-181.

7. Floras JS, Wesche J. Haemodynamic contributions to post-exercise hypotension in young adults with hypertension and rapid resting heart rates. J Hum Hypertens. 1992;6(4):265-9.

8. Rondon MUB, Alves MJ, Braga AM, Teixeira OT, Barretto AC, Krieger EM, et al. Postexercise blood pressure reduction in elderly hypertensive patients. J Am Coll Cardiol. 2002;39(4):676-82.

9. Coats AJ, Conway J, Isea JE, Pannarale G, Sleight $P$, Somers VK. Systemic and forearm vascular resistance changes after upright bicycle exercise in man. J Physiol. 1989;413:289-98.

10. Isea JE, Piepoli M, Adamopoulos S, Pannarale G, Sleight $P$, Coats AJ. Time course of haemodynamic changes after maximal exercise. Eur J Clin Invest. 1994;24(12):824-9.

11. Archer SL, Huang JM, Hampl V, Nelson DP, Shultz PJ, Weir EK. Nitric oxide and cGMP cause vasorelaxation by activation of a charybdotoxinsensitive $\mathrm{K}$ channel by CGMP-dependent protein kinase. Proc Natl Acad Sci USA. 1994;91(16):7583-7.

12. Tanaka Y, Tang G, Takizawa K, Otsuka K, Eghbali $\mathrm{M}$, Song $\mathrm{M}$, et al. Kv channels contribute to nitric oxide- and atrial natriuretic peptide-induced relaxation of a rat conduit artery. J Pharmacol Exp Ther. 2006;317(1):341-54.

13. Breuillard C, Cynober L, Moinard C. Citrulline and nitrogen homeostasis: An overview. Amino Acids. 2015;47(4):685-91.

14. Alsop P, Hauton D. Oral nitrate and citrulline decrease blood pressure and increase vascular conductance in young adults: A potential 
therapy for heart failure. Eur J Appl Physiol. 2016;116(9):1651-61.

15. Gordon CC, Chumlea WC, Roche AF. Stature, recumbent length, and weight. In Lohman TG, Roche $A F$, Martorell $R$, editors. Champaign: Human Kinetics Books; 1988. p.3-8

16. Coleman A, Freeman P, Steel S, Shennan A. Validation of the Omron MX3 Plus oscillometric blood pressure monitoring device according to the European Society of Hypertension international protocol. Blood Press Monit. 2005;10(3):165-8.

17. Pickering TG, Hall JE, Appel $\amalg$, Falkner $B E$, Graves J, Hill MN, et al. Recommendations for blood pressure measurement in humans and experimental animals: Blood pressure measurement in humans: A statement for professionals from the Subcommittee of Professional and Public Education of the American Heart Association Council on High Blood Pressure Research. Hypertension. 2005;45(1):142-61.

18. Casonatto J, Tinucci T, Dourado AC, Polito M. Cardiovascular and autonomic responses after exercise sessions with different intensities and durations. Clinics. 2011;66(3):453-8.

19. Bendahan D, Mattei JP, Ghattas B, ConfortGouny S, Le Guern ME, Cozzone PJ. Citrulline/ malate promotes aerobic energy production in human exercising muscle. Brit J Sports Med. 2002;36(4):282-9.

20. Sureda A, Cordova A, Ferrer MD, Tauler $P$, Perez G, Tur JA, et al. Effects of L-citrulline oral supplementation on polymorphonuclear neutrophils oxidative burst and nitric oxide production after exercise. Free Radic Res. 2009;43(9):828-35.

21. Schwedhelm E, Maas $R$, Freese $R$, Jung D, Lukacs $Z$, Jambrecina $A$, et al. Pharmacokinetic and pharmacodynamic properties of oral L-citrulline and L-arginine: Impact on nitric oxide metabolism. Brit J Clin Pharmacol. 2008;65(1):51-9.

22. Mori M. Regulation of nitric oxide synthesis and apoptosis by arginase and arginine recycling. J Nutr. 2007;137(6Suppl.2):1616S-20S.

23. Figueroa A, Wong A, Jaime SJ, Gonzales $\mathrm{JU}$. Influence of L-citrulline and watermelon supplementation on vascular function and exercise performance. Curr Opin Clin Nutr Metab Care. 2017;20(1):92-8.

24. Wong A, Alvarez-Alvarado S, Jaime SJ, Kinsey AW, spicer MT, Madzima TA, et al. Combined whole-body vibration training and I-citrulline supplementation improves pressure wave reflection in obese postmenopausal women. Appl Physiol Nutr Metab. 2016;41(3):292-7.
25. Hagberg JM, Montain SJ, Martin WH. Blood pressure and hemodynamic responses after exercise in older hypertensives. J Appl Physiol. 1987;63(1):270-6.

26. Casonatto J, Polito MD. Hipotensão pós-exercício aeróbio: uma revisão sistemática. Rev Bras Med Esporte. 2009;15(2):151-7.

27. Carpio-Rivera E, Moncada-Jimenez J, Salazar-Rojas W, Solera-Herrera A. Acute effects of exercise on blood pressure: A meta-analytic investigation. Arq Bras Cardiol. 2016;106(5):422-33.

28. Li Q, Youn JY, Cai H. Mechanisms and consequences of endothelial nitric oxide synthase dysfunction in hypertension. J Hypertens. 2015;33(6):1128-36.

29. Joannides R, Haefeli WE, Linder L, Richard V, Bakkali $E H$, Thuillez C, etal. Nitric oxide is responsible for flowdependent dilatation of human peripheral conduit arteries in vivo. Circulation. 1995;91(5):1314-9.

30. Ochiai M, Hayashi T, Morita M, Ina K, Maeda M, Watanabe F, et al. Short-term effects of L-citrulline supplementation on arterial stiffness in middleaged men. Inter J Cardiol. 2012;155(2):257-61.

31. Wijnands $K A$, Vink $H$, Briede JJ, van Faassen $E E_{\text {, }}$ Lamers WH, Buurman WA, et al. Citrulline a more suitable substrate than arginine to restore NO production and the microcirculation during endotoxemia. Plos One. 2012;7(5):e37439.

32. El-Hattab AW, Hsu JW, Emrick LT, Wong LJ, Craigen WJ, Jahoor F, et al. Restoration of impaired nitric oxide production in MELAS syndrome with citrulline and arginine supplementation. Mol Gen Metab. 2012;105(4):607-14.

33. Luiking YC, Poeze M, Ramsay G, Deutz NE. Reduced citrulline production in sepsis is related to diminished de novo arginine and nitric oxide production. Am J Clin Nutr. 2009;89(1):142-52.

34. Chobanian AV, Bakris GL, Black HR, Cushman WC, Green LA, Izzo Junior JL, et al. Seventh report of the Joint National Committee on Prevention, Detection, Evaluation, and Treatment of High Blood Pressure. Hypertension. 2003;42(6):1206-52.

35. Wax B, Kavazis AN, Luckett W. Effects of supplemental citrulline-malate ingestion on blood lactate, cardiovascular dynamics, and resistance exercise performance in trained males. J Diet Suppl. 2016;13(3):269-82.

36. Kelley GA, Kelley KS. Progressive resistance exercise and resting blood pressure: A meta-analysis of randomized controlled trials. Hypertension. 2000;35(3):838-43.

37. Cornelissen VA, Smart NA. Exercise training for blood pressure: A systematic review and metaanalysis. J Am Heart Assoc. 2013;2(1):e004473. 
38. Anunciação PG, Casonatto J, Polito M. Blood pressure responses and heart rate variability after resistance exercise with different intensities and same workload. Int Sport J. 2011;12(2):53-67.

39. Casonatto J, Goessler KF, Cornelissen VA, Cardoso $J R$, Polito MD. The blood pressure-lowering effect of a single bout of resistance exercise: A systematic review and meta-analysis of randomised controlled trials. Eur J Prev Cardiol. 2016;23(16):1700-14.

40. Moraes MR, Bacurau RF, Simoes HG, Campbell CS, Pudo MA, Wasinski $F$, et al. Effect of 12 weeks of resistance exercise on post-exercise hypotension in stage 1 hypertensive individuals. J Hum Hypertens. 2012;26(9):533-9.
41. Mota MR, Oliveira RJ, Dutra MT, Pardono E, Terra DF, Lima RM, et al. Acute and chronic effects of resistive exercise on blood pressure in hypertensive elderly women. J Strength Cond Res. 2013;27(12):3475-80.

42. Sullivan GM, Feinn R. Using effect size or why the $p$ value is not enough. J of Grad Med Educ. 2012;4(3):279-82

43. Lakens D. Calculating and reporting effect sizes to facilitate cumulative science: A practical primer for t-tests and ANOVAs. Front Psychol. 2013;4:863.

Received: October 4, 2018

Final version: December 12, 2018

Approved: December 18, 2018 